\title{
OECDpublishing
}

\section{THE WAVE OF JIHADIST INSURGENCY IN WEST AFRICA}

\section{WEST AFRICAN PAPERS}

\section{August 2017 No. 07}





\section{THE WAVE OF JIHADIST INSURGENCY IN WEST AFRICA: GLOBAL IDEOLOGY, LOCAL CONTEXT, INDIVIDUAL MOTIVATIONS}

This paper has been prepared by IBRAHIM YAHAYA IBRAHIM

Sahel Research Group, University of Florida 


\section{WEST AFRICAN PAPERS}

The West African Papers series explores African socio-economic, political and security dynamics from a regional and multidisciplinary perspective. It seeks to stimulate discussion and gather information to better anticipate the changes that will shape future policies. The series is designed for a wide audience of specialists, development practitioners, decision makers and the informed public. Papers are available in English and/or French, and summaries are available in both languages. Initiated by the Sahel and West Africa Club (SWAC) to highlight and promote West African issues, the work presented is prepared by its Secretariat, Members and partners, other OECD departments, related international organisations, associated experts and researchers.

For more information on the Sahel and West Africa Club: http://www.oecd.org/swac.

Please cite this publication as:

Ibrahim, I.Y. (2017), “The Wave of Jihadist Insurgency in West Africa: Global Ideology, Local Context, Individual Motivations”, West African Papers, No. 07, OECD Publishing, Paris. http://dx.doi.org/10.1787/eb95c0a9-en

Author contact: abrayaima@gmail.com

ISSN 2414-2026

OECD Working Papers should not be reported as representing the official views of the OECD or of its member countries. The opinions expressed and arguments employed are those of the authors.

This document and any map included herein are without prejudice to the status of or sovereignty over any territory, to the delimitation of international frontiers and boundaries and to the name of any territory, city or area.

Working Papers describe preliminary results or research in progress by the author(s) and are published to stimulate discussion on a broad range of issues on which the OECD works. Comments on Working Papers are welcomed, and may be sent to the Sahel and West Africa Club, OECD, 2 rue André-Pascal, 75775 Paris Cedex 16, France.

Authorised for publication by Laurent Bossard, Director, Sahel and West Africa Club Secretariat (SWAC/OECD).

(C) OECD 2017

You can copy, download or print OECD content for your own use, and you can include excerpts from OECD publications, databases and multimedia products in your own documents, presentations, blogs, websites and teaching materials, provided that suitable acknowledgment of OECD as source and copyright owner is given. All requests for commercial use and translation rights should be submitted to rights@oecd.org.. 


\begin{abstract}
The recent rise of jihadist movements in West Africa, including Boko Haram in the Lake Chad region and Al-Qaeda in the Islamic Maghreb and its affiliates in the Sahel-Saharan region, has puzzled many observers. The easy spread of the jihadist ideology, the jihadist movements' success in massively recruiting followers among local populations as well as their ability to conquer and administer territories, are unprecedented in the region's contemporary history. This paper sheds light on the factors and processes that contribute to the emergence of these movements. It argues that the phenomenon of jihadist insurgencies in West Africa emerges as a result of a series of processes at the global, local, and individual level. At the global level, there is the formation and dissemination of the global ideology of jihadism, conceptualised by Muslim activists and scholars based on a particular understanding of Islam and the challenges that are facing contemporary Muslim societies. At the local level, the appropriation of jihadist ideologies by "Muslim activists" who then use it to formulate a discourse which taps into local social and political demands in order to mobilise followers, is key. For a wide range of reasons, certain regions of Africa have experienced weakened state capacity and increased local conflict, and it is in these areas that jihadist insurgencies have emerged. At the individual level, the process by which African individuals decide to enrol in jihadist groups include ideological, situational, and strategic motivations, and these have all been facilitated by deteriorating conditions of life in marginalised areas.
\end{abstract}

Keywords: jihadism, terrorism, Islamism, Sahara-Sahel, West Africa

JL classification: D74, F5, H56, N47

\begin{abstract}
ABOUT THE AUTHOR
Ibrahim Yahaya Ibrahim is a Ph.D. Candidate in the Department of Political Science and a Research Associate with the Sahel Research Group at the University of Florida. His dissertation research focuses on Political Contestation and Islamic Discourses in the Sahel region, with a particular focus on Mali, Mauritania, and Niger.
\end{abstract}

\title{
NOTE TO READERS
}

This Note is published as part of the partnership between SWAC/OECD and the Sahel Research Group of the University of Florida. The collaboration aims to:

1. Reinforce ties between research and policies for sustainable development that can help better anticipate changes within the Sahel and West Africa Region.

2. Promote West African expertise by reinforcing the links with African researchers and research centres through the Sahel Research Group network. 



\section{TABLE OF CONTENTS}

CONTEXT

THE WAVE OF JIHADIST INSURGENCY IN WEST AFRICA

JIHADISM: THE GLOBAL IDEOLOGICAL FOUNDATIONS OF JIHAD

THE IMPORTANCE OF LOCAL CONTEXT IN THE RISE OF JIHADIST ENTREPRENEURS.

INDIVIDUAL MOTIVATIONS OF “RANK AND FILE” JIHADISTS

POLICY RELEVANT CONCLUSIONS

\section{CONTEXT}

O ver the last decade and a half, many regions in Africa have experienced a surge of jihadist insurgency, notably by Al-Qaeda in the Islamic Maghreb (AQIM) in the Sahelo-Saharan region, Boko Haram in the Lake Chad region, Al-Shabaab in the Horn of Africa, and Ansari al-Sharia and the Islamic State in the Maghreb (ISIS). These groups have carried out numerous attacks that have resulted in tens of thousands of casualties and the displacement of millions of people (Figure 1). Between 2002 and 2017, sixteen African countries have been affected by Jihadist attacks, ranging from the kidnapping and abduction of civilians to sporadic assaults on military barracks, suicide bombings in churches, mosques, schools and markets, as well as the occupation and attempts to set up jihadist administration of territories. Thousands of young Africans from a variety of social and economic backgrounds have fallen prey to the lure of jihadist discourse. Many of them have rallied to the jihadist groups that operate on the continent, while others have fought on the side of ISIS in Syria and Iraq (Benmelech and Klor, 2016: 16). As ISIS loses control over its strongholds in the Middle East, the threat that some jihadists may seek refuge on the continent is quite significant. All these developments bear witness to the fact that the African continent has become one of the hotbeds of jihadism in the world.

The new wave of jihadist insurgency, particularly evident in West Africa, has puzzled many observers. How did these regions, where societies have historically been known for their peaceful practice of Islam, end up developing some of the deadliest jihadist movements in the world? And why, despite significant similarities among most of the countries affected, has jihadism tended to develop in some particular places, and not in others? Who are the West African jihadists? What are their profiles and motivations? This paper takes up the challenge to attempt to answer these questions by focusing more particularly on two influential jihadist movements in West Africa: AQIM and Boko Haram.

The major argument of this paper is that the wave of jihadist insurgencies in Africa must be understood as a concatenation of processes at three levels: global, local, and individual. There is, first, a global jihadist ideology that some canonic Muslim activists and scholars have conceptualised - and disseminated throughout the world - based on a particular understanding of Islam and in response to the challenges faced by contemporary Muslim societies. This jihadist ideology is at times appropriated by local Muslim activists in Africa who then use it to formulate a discourse tailored to tap into local grievances in order to justify violence against the state and other non-Muslims, and framed as a contribution to establishing the Islamic Caliphate and Sharia rule. Large numbers of individuals from different social and economic backgrounds, motivated by a variety of factors, including religious, situational, and strategic, have enrolled in these jihadist movements. Each of these levels must be considered in attempting to understand contemporary jihadist insurgencies in West Africa. 
Figure 1

Fatalities related to all groups (in red) and Islamist groups (in green), 1997-2015

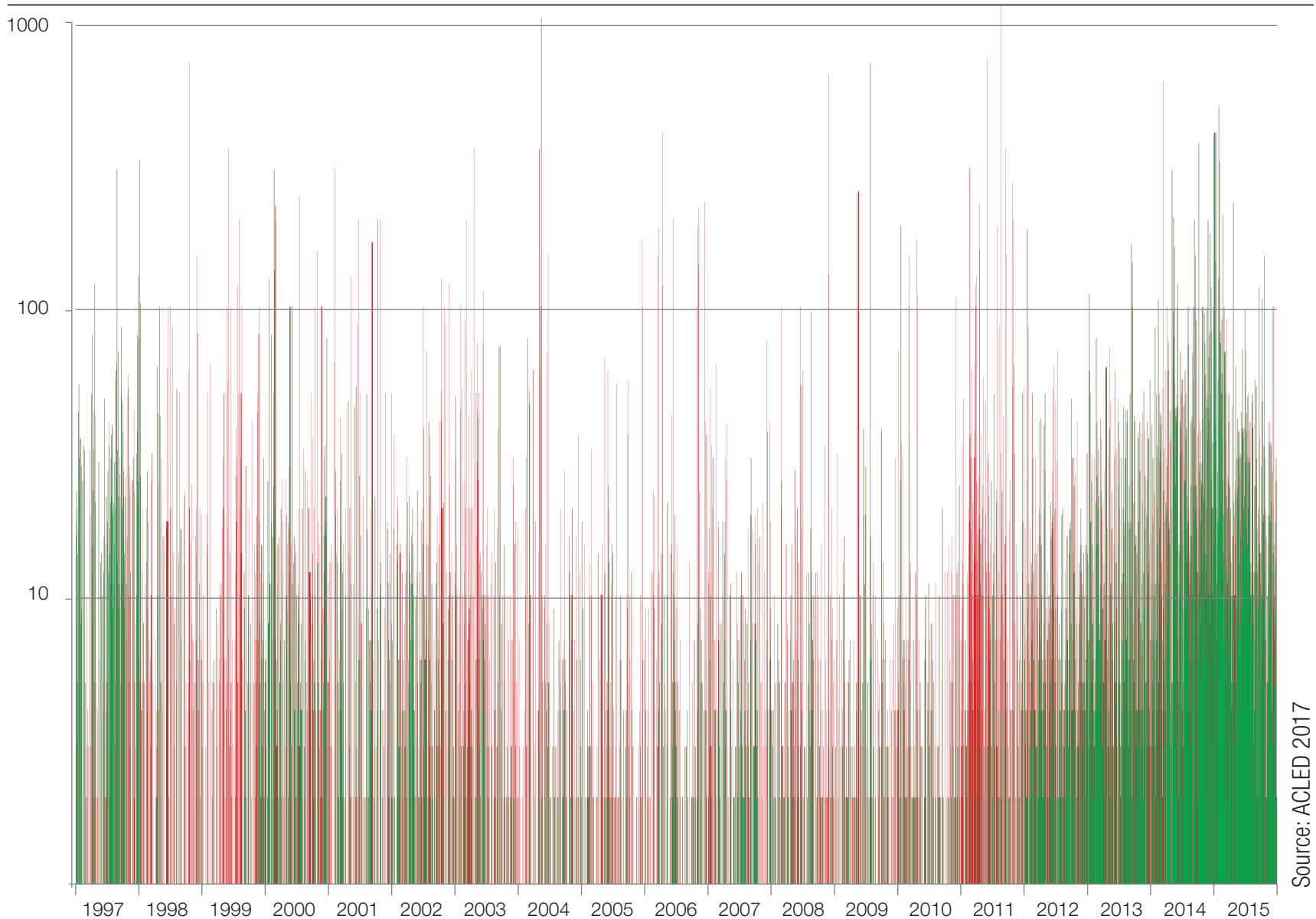

THE WAVE OF JIHADIST INSURGENCY IN WEST AFRICA

\begin{abstract}
The beginning of the new wave of African jihadist insurgencies goes back to the early 2000s when the 9/11 attacks and the so-called "War on Terror" popularised the jihadist ideology throughout the world. The context of political instability and civil conflicts that marked some African countries in the 1990s facilitated the emergence of the first jihadist movements. Some of these jihadist movements are, in fact, direct offshoots of pre-existing conflicts. AQIM emerged out of the Algerian Civil War, which started in 1991 following the Islamists' victory in the first democratic elections and the subsequent military coup that denied them power (Abul Ma'ali, 2014). The Islamists waged a violent campaign against the junta aimed essentially at reclaiming their electoral victory. The conflict continued from 1991 to 2002 when a radical branch of the Islamist insurgents, called the Salafist Group for Preaching and Combat (GSPC in the French acronym), adopted Al-Qaeda's jihadist ideology and shifted the focus of the insurgency from regime change in Algeria to waging jihad throughout the Sahelo-Saharan region. The GSPC changed its name in 2007 to reflect this strategic shift from domestic conflict to regional jihad.
\end{abstract}

Yet, jihad is not a completely new phenomenon in West Africa. During the nineteenth century, the region of West Africa witnessed the rise of the so-called Fulani or Sufi jihads waged by Sufi sheikhs from the Fulani ethnic group, against the Hausa and Bambara kingdoms (Idrissa, 2009: 30). These early jihadist wars led to the formation of the Sokoto Empire (1804-1903), the Macina Empire (1820-1862), and the Toucouleur Empire (1848-1893) (Map 1). The nineteenth century Fulani jihads, however, were different from contemporary jihadist insurgencies, which endorse an ideology that is epistemologically different from Sufism, and have social bases that are significantly more diverse. One key characteristic 


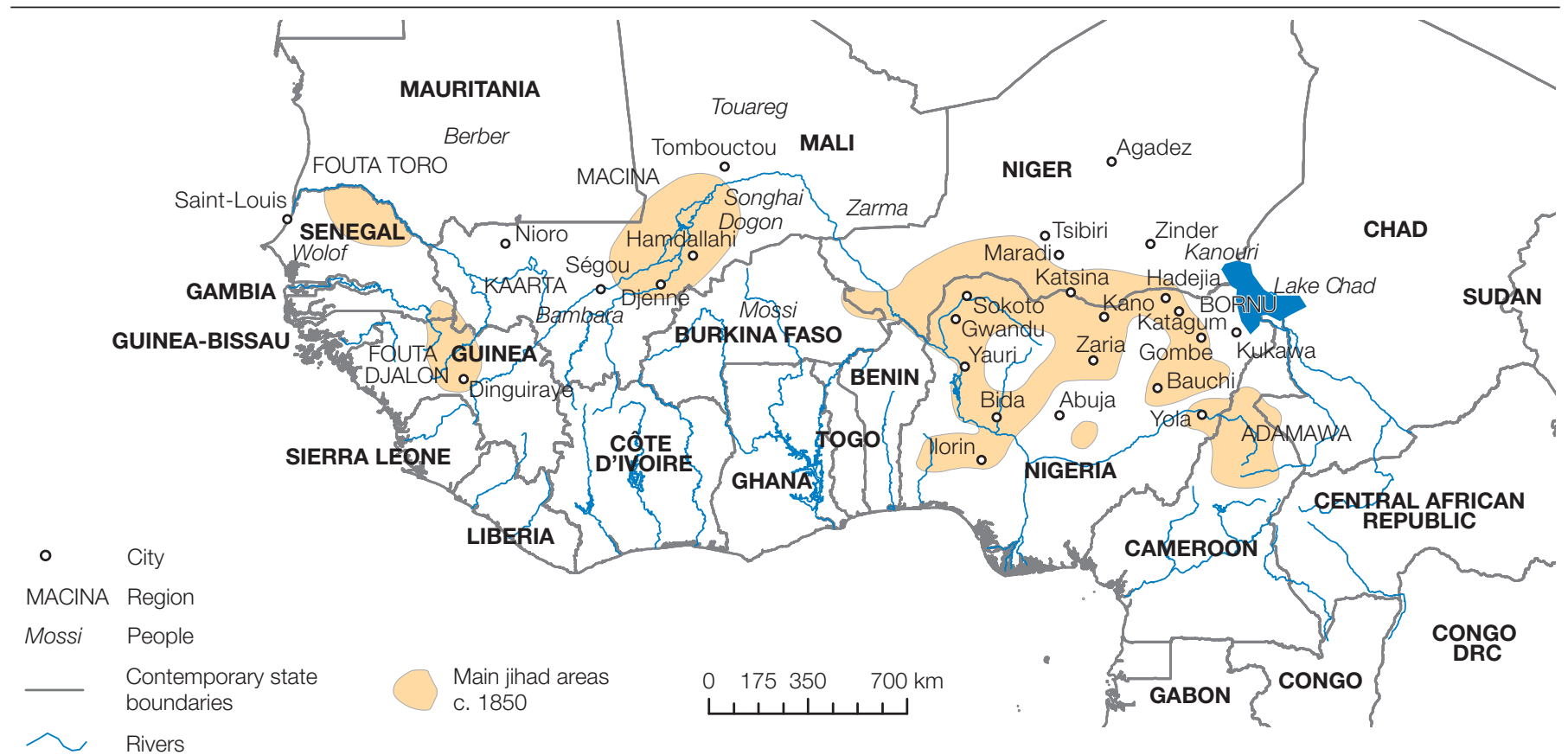

Source: Walther and Miles (forthcoming in 2018); cartography: Olivier Walther 2017

of the contemporary African jihadist movement is its ability to mobilise large numbers of adherents from different social and economic backgrounds, and beyond the limits of prevailing ethnic, tribal, and racial cleavages. This inclusiveness is largely due to the fact that in many West African societies, Islam constitutes a broader identity that spans across ethnic and tribal lines. In their discourse, African "jihadists entrepreneurs" strongly emphasise the necessity for Muslims to overcome ethnic and tribal fragmentations. Thus, for example, departing from a well-established tradition in previous Tuareg rebellions, Iyad Ag Ghali, the leader of Ansar Dine has insistently called for the union of all Muslims in northern Mali - Tuareg, Arabs, Fulani, Songhai, and Bambara - to fight against "Western crusaders" and their local allies ("Liqa'a ma'a Abul Fadl," 2017). Some of his propaganda videos feature Muslim clerics from Tuareg, Arab, and Fulani communities preaching for unity and jihad against infidels (Imazighen Libya TV, 2013).

While drawing on religion has allowed Jihadists to mobilise adherents from across ethnic and tribal groups, this inclusiveness does not make jihadist movements homogenous or unified. To the contrary, jihadist movements constitute a loose coalition of groups that are divided along the same cleavages that they try to overcome. AQIM, for instance, has suffered internal divisions that were paradoxically related to nationality and ethnicity. The creation of the Movement for Oneness and Jihad in West Africa (MUJAO in the French acronym), in fact, came as a result of tensions over the leadership of the movement between the Algerians and the Malian Arabs. The later accused the former of hijacking all of the positions of leadership within AQIM, and of a double standard policy in the treatment of Tuareg and Arab jihadists. These accusations justified Malian Arabs' decision to split from AQIM and to create MUJAO (Abul Ma'ali, 2014). Another significant point of contention within jihadist movements concerns the appropriateness of targeting Muslim civilians. Thus the group Jama'atu Ansaril Muslimina fi Biladis Sudan - commonly known as Ansaru - split from Boko Haram in 2012 to focus on international targets after condemning Boko Haram's atrocity against Muslim civilians (Mohammed, 2014).

Despite these major internal divisions, however, jihadist insurgencies in Africa have proven capable of major disruptions with serious consequences. Both AQIM and Boko Haram have succeeded in conquering and administering territories, albeit temporarily. 
AQIM and its affiliates occupied two-thirds of the Malian territory for nine months, between April 2012 and January 2013. Boko Haram conquered and held significant territory in northeastern Nigeria between 2014 and 2016. The jihadist movements' ability to govern the territories under their control, however, has varied significantly. While AQIM and its affiliates in northern Mali created a government with a fairly functioning administration, a judicial system, as well as an attempt to provide public services such as running a hospital, distributing humanitarian aid and policing, Boko Haram's governance in northeastern Nigeria was limited to harsh implementation of the Sharia penal code.

Taxation, ransoms, and illicit trafficking have constituted jihadists' major sources of income. Taxation of local businesses in areas controlled by jihadists, and participation in criminal business such as kidnapping for ransom and drug trafficking, have provided West African jihadists with millions of dollars. AQIM is suspected to have gained around USD 120 million in ransoms alone (OECD, 2013: 93). Similarly, Boko Haram has extracted millions of dollars of taxes from the fishing and pepper business around Lake Chad (Oxfam, 2017). There have been many claims of donations by Islamic humanitarian non-governmental organisations (NGOs) and other donors from the Persian Gulf to jihadist movements in Africa, but no clear evidence to substantiate these claims has been produced (Ryder, 2015: 9).

The connections between African jihadist movements and global jihadist organisations have raised concerns as African movements increasingly declared their allegiance to ISIS or Al-Qaeda (Siegel, 2017). While these affiliations confer a seeming global connectedness to African jihadist movements, their importance should not be overstated. Analysed more closely, African jihadist movements are first and foremost local movements that arise from local social and political dynamics, and their struggle is primarily geared toward addressing local - not global - grievances. Similarly, suspicions about African jihadist movements' attempts to join forces and co-ordinate their activities have frequently raised concerns. But while there is significant evidence of contacts between AQIM and Boko Haram, through such means as the exchange of letters and training missions, these contacts have remained superficial. There is no evidence of any co-ordinated attacks carried out jointly by AQIM and Boko Haram. Rather, each of these groups has focused its activism within its area of influence. Alleged connections between different jihadist movements in Africa do not change the centrality of the local context.

\section{JIHADISM: THE GLOBAL IDEOLOGICAL FOUNDATIONS OF JIHAD}

A frican jihadist movements share some distinctive ideological views that can be summarised in three major points. First, Islam is at war with the West and its local allies in Muslim societies, and militarily confronting the enemies of Islam is a religious duty. Second, the nation-state system, state institutions, and democracy are un-Islamic and need to be replaced with the system based on the Caliphate and Sharia law. Third, Muslims can be declared "apostates" or "unbelievers" if they commit major sins, and in which case they can be legitimately targeted with violence. These three ideas are the quintessence of jihadism, a global ideology that has motivated and justified jihadist insurgencies around the world.

Jihadism is not a theological sect, such as Sufism or Salafism - which focus essentially on the interpretation of religious doctrine and ritual practices - but rather a political ideology that claims to provide a coherent interpretation of social and political problems facing Muslim societies. As such, jihadism competes with pietism and Islamism, each drawing on a particular Islamic epistemology and jurisprudence to justify their views. Jihadism in particular draws justification for its extreme political views and behaviours from a largely Salafi reading of the Islamic scriptures.

Canonic Muslim activists, such Abdallah Azzam (1941-1989), Abu Muhamad Al-Maqdissi (b. 1959), and Usama Ben Laden (1957-2011) pioneered the conceptualisation of jihadism 
based on their interpretations of three key concepts and principles. First, the concept of Al-wala' wal bara', which means literally "loyalty and disavowal" and, in jihadist interpretation, is a principle that stipulates that a Muslim must show exclusive loyalty toward his fellow Muslims and the Muslim community worldwide, and disavow all non-Muslims and non-Muslim systems (Thurston, 2016: 211). This principle codifies Muslims' relation to non-Muslims exclusively based on religious beliefs. In other words, "love" and "hate" are to be determined solely by the religious orientation of the other. The second concept is Al-Hakimiyyah, meaning "sovereignty," which defines the jihadists' view of political institutions and authority (the nation-state, democracy, constitutions, etc.). According to the jihadist interpretation of this principle, sovereignty belongs only to God. No state or regime can exercise sovereignty except on behalf of God, and in compliance with Sharia law (Kepel, 1984: 48). Jihadists reject the constitutions of modern Muslim states for non-compliance with the principle of God's sovereignty, just as they reject democracy for conferring sovereignty to people as opposed to God. The third concept is Takfir (excommunication) which determines the boundary of who is Muslim and who is an infidel, and specifies under what circumstances a Muslim can be excommunicated and with what consequences (Brigaglia, 2015: 185-186).

While all jihadist ideologues emphasise these principles in their discourse, there is no agreement between them on their specific interpretation. In particular, the interpretation of the principle of excommunication (Takfir) has been a matter of important controversy among jihadist ideologues, leading to the recent split between what has been called the "Al-Qaeda approach" and the "ISIS approach" to jihad. The former offers a narrow definition of the concept of Takfir, restricting its scope of application to non-Muslims, whereas the latter stretches the definition of the concept, broadening its scope of application to include Muslims who disagree with the view of Islam propagated by ISIS (Al-Maqlaat, 2016). Given that jihad is only waged against non-Muslims, the definition of the concept of Takfir has practical consequences in terms of who becomes a target of violence. Jihadist groups that have adopted ISIS conceptualisation, most significantly Boko Haram, have tended to engage in indiscriminate killing of civilians, targeting Muslims and non-Muslims alike. By contrast, groups such as AQIM, that endorse the Al-Qaeda approach have tended to spare civilian lives, and focused rather on targeting Western and state interests.

Ideology plays a significant role in the development of jihadist insurgency. First, ideology provides a lens through which jihadists view the world and reinterpret local realities. Most of the grievances that jihadists groups address in their discourse are not new. Grievances vis-à-vis the West, for instance, have been a constant in West Africa, expressed through denunciation of colonialism and accusation of the West's illegitimate exploitation of West Africa's riches, yet these have not often led to violence against Westerners. The re-interpretation of these old grievances in jihadist terms, such as "colonial crusades," or "infidels' assault" on Muslim culture and resources, however, has infused them with a different significance and justified violence against the West and its interests. Second, ideology redraws the in-group and out-group boundaries between Muslims and non-Muslims, or between jihadists and the larger population, and gives moral justification for violence against out-group elements. In the region of Lake Chad, for example, the Buduma fishermen have for decades accused Hausa settlers of depriving them of economic resources, but these grievances have never amounted to mass violence, partly because both Hausa and Buduma communities are Muslims and religion has facilitated the diffusion of communal tensions. Yet with the spread of Boko Haram ideology in the region, many members of the Buduma communities adopted the jihadist ideology and reinterpreted Hausa trade practices as usury - a practice that is condemned in Islam - and as a result declared the Hausa traders as apostates and thus legitimate targets for violence. This reinterpretation of the old grievances has justified the massive and abject violence perpetrated by Boko Haram against Hausa villages in and around Lake Chad (Seignobos, 2016). Third, the jihadist ideology serves as a source of motivation for individuals to engage in jihad, as will be further developed below. 


\section{THE IMPORTANCE OF LOCAL CONTEXT IN THE RISE OF JIHADIST ENTREPRENEURS}

deology is a necessary but not sufficient condition for the development of a jihadist

insurgency. In fact, there is no insurgency without leadership or "first movers," who call for it and organise it. First movers frame the discourse, decide that insurgency is the only way to achieve goals, provide the arguments that morally justify violence, and convince their followers that despite all the risks, insurgency is likely to work (Sedgwick, 2007: 16). For a jihadist insurgency to emerge, jihadist ideology has to be appropriated by local Muslim activists - or "jihadist entrepreneurs" - who then use it to formulate a more pointed discourse that resonates well with the local social and political demands. The context in which these jihadist entrepreneurs emerge, as well as the process by which they frame their discourse and mobilise followers, are determinant for the occurrence of insurgency. African jihadist entrepreneurs tend to emerge in a context of political opportunity provided by various factors: the state's ability to govern is limited, society is highly divided, and state challengers are inclined to resort to violence to express social and political grievances. In other words, jihadist insurgent groups tend to emerge in a context of ongoing conflict and take advantage of this conflict situation to grow and establish themselves (International Crisis Group, 2016).

Most African states are neither fully "Weberian states" that have complete monopoly of legitimate use of force across their territory, nor are they "ungoverned territories" or "failed states." They are rather states with varied levels of statehood, meaning their monopoly over the means of violence and their ability to make and implement policies is not uniform throughout their territories (Herbst, 2000; Krasner and Risse, 2014). Despite their weak capacities, most states in Africa have "consolidated statehood" at least in their capital cities; that is, they possess the military and administrative capacities to regulate social behaviour and resolve conflict in these places. This is different, however, in rural and remote areas where states may have only "limited statehood". Jihadist entrepreneurs have tended to establish their bases in peripheral areas where the state has only a limited statehood because these areas offer a bigger opportunity to organise insurgencies. Although jihadists may infiltrate areas of consolidated statehood to stage attacks, they are rarely able to establish bases there. Even in the rare cases where jihadist movements have established cells in metropolitan areas - such as Ansarullah Al Murabitun fi Bilad as-Shinguit in Nouakchott in Mauritania between 2008 and 2011, and Boko Haram in the city of Maiduguri in northeastern Nigeria - these insurgencies were either easily overcome by the state, or the jihadists were obliged to withdraw to rural areas to escape state crackdown.

Yet, not all areas of limited statehood provide equal opportunity for insurgency. Deeply divided societies in areas of limited statehood present a higher risk of nurturing jihadist entrepreneurs. Areas of limited statehood in Africa, in fact, are not necessarily "ungoverned" spaces (Risse, 2011). Rather, they are often governed by non-state actors, notably traditional chiefs who have been quite successful in maintaining social control and enforcing customary law. In recent years, however, the authority and legitimacy of traditional authorities in many areas have eroded due to decentralisation reforms. New actors, including local political elites, religious leaders, and rebel leaders, have emerged and competed for social and political control. While this competition has been peaceful in places where society is more homogenous and where informal rules and norms have remained effective, in places where society is deeply divided - either along religious or ethnic lines - and where informal norms are contested, competition between actors has exacerbated tensions and often fuelled conflict. It is in these particular local contexts, that most African jihadist entrepreneurs have emerged.

For example, Muhammad Yusuf - the leader of Boko Haram - emerged as an important leader in the context of declining authority of traditional rulers in northern Nigeria and the rise of religious sectarianism, with multiple religious sects competing not only over 
the sacred but also over followership and political access (Last, 2008). The prestige of a sect leader is largely dependent on the significance of his followership; the more followers a cleric has, the more politicians woo him. And the more political access he has, the more resources he earns to invest in his followers and consolidate his basis. As Murray Last (2008: 10) has argued, Muhammad Yusuf was one of these rising sect leaders who needed to "stand out from the crowd with a message that is radical enough to attract attention... He may, however, have pushed it to more of an extreme than usual." Similarly, Iyad ag Ghali emerged as the leader of Ansar Dine in a context of limited statehood, and within a society that was deeply divided along ethnic, tribal, and factional lines, and where informal authorities and customary norms are contested (Lecocq and Schrijver, 2007: 156-157). Iyad was one of many other "big men" who vied for social and political control in northern Mali and who worked as a broker between conflicting parties (Walther and Christopoulos, 2015). His adoption of the jihadist ideology came only after his failure to capture the leadership of the secular National Movement for the Liberation of Azawad (Bøås, 2015: 307).

\section{INDIVIDUAL MOTIVATIONS OF "RANK AND FILE” JIHADISTS}

$\mathrm{T}$

he motivation of jihadist entrepreneurs to initiate an insurgency may not be the same as the rank and file jihadists who comprise it. The diverse backgrounds of these fighters have frustrated attempts to draw the profile of a "typical jihadist". A recent study of the motivations of Boko Haram combatants concludes that "[t]here is no demographic profile of Boko Haram members... Some had jobs, and others did not. Some had attended secular school, others Islamic school, and others had dropped out. Profiling in youth interventions based on demographics or other assumed risk factors is unlikely to be successful" (Mercy Corps, 2016). Jihadist recruits have different motivations that may be religious, situational, or strategic. And these different motivations are not mutually exclusive, but rather may be complementary.

Religious belief is an important motive for many people who enrol in jihadist groups. During an interview in Gao, a former MUJAO recruit explained his enrolment decision in these terms, "I was praying in the mosque when the Mujaheedin entered Gao. As I heard them shouting 'Allahu Akbar, Allahu Akbar, Allahu Akbar,' my body started shaking. I could feel it in my bones that the time has come for Islam to rule. The next day I went to MUJAO's headquarter and registered for military training." In northern Mali, members of the Tabligh Jama'at and the so-called "Wahariji sect" were among the first to embrace jihadism, whereas in northeastern Nigeria, Boko Haram arose from within the Salafi movement Ahlu as-Sunna wal Jama'a (Thurston, 2016: 205-207). It is important to note that leaders of all major religious sects, including Sufism, mainstream Salafism, and Tabligh Jama'at, have rejected jihadism as a deviant ideology. Yet, the fact that Salafism, the Tabligh Jama'at, and the Wahariji sect each have some doctrinal proximity with jihadism has made a few members of these sects more predisposed to accept the jihadist discourse.

An individual's enrolment in jihadist groups is also clearly dictated by situational and contingent factors. The dynamics of conflict and situations of insecurity have forced some communities in quest of protection to pledge allegiance to jihadist movements. This is particularly the case with Fulani pastoralists in northern and central Mali and in northeastern Burkina Faso. Hundreds of members of Fulani militias joined MUJAO in 2012 in an alliance against their Tuareg rivals (Sangare, 2016). Kinship networks also play a significant role in determining who enrols in jihadist movements. Jihadist entrepreneurs are most often successful in initially recruiting supporters from within their immediate family, clan, and ethnic group before expanding to other networks. Not only do family and tribal ties facilitate recruitment, but also in a context of widespread insecurity, family and tribe are valuable sources of protection against rival communities, leaving individuals with no choice but to enrol in the group supported by their communities. 
Other individuals, especially those associated with illicit trafficking and other criminal networks, may join jihadist movements for business and strategic reasons. In northern Mali, jihadists have provided protection to drug traffickers and other criminal networks, and these networks have in turn helped jihadists in kidnapping operations and conducting terrorist attacks. Recent media reports suggest that the jihadist group called Al-murabitun "subcontracted" the January 2016 attacks on a hotel and a café in Ouagadougou to a criminal network led by Mimi Baba Ould Cheikh, operating in the Gao region, for the amount of ten million FCFA (about USD 17 000) (Le Cam, 2017). Other individuals have joined jihadist movement for financial incentives, including salaries, the distribution of booty, and, for young men who cannot otherwise afford it, the enticing opportunity for marriage to abducted women or female jihadists (Matfess, 2016).

Finally, the counter-terrorism measures that governments took to fight the jihadist insurgencies have themselves often fuelled grievances and boosted enrolment in jihadist groups. Measures aiming to deprive Boko Haram of financial resources led Chad, Niger and Nigeria to ban the commercialisation of pepper and fish, which constitute the two most important sources of income in the Lake Chad region (Oxfam, 2017).

\section{POLICY RELEVANT CONCLUSIONS}

$\mathbf{J}$

ihadist insurgency in West Africa is often viewed as a "foreign phenomenon" that is either organized and led by external actors or motivated by a "foreign ideology" (Holder, 2009; Sambe, 2014: 11). This view is based on the separation between what is considered "African Islam," referring to the Sufi tradition that had dominated the African Islamic sphere until the early 1990s, and "Islam in Africa," which refers to the reformist trends of Islam - particularly Salafism - that is largely viewed as "imported" from the Middle East (Westerlund and Rosander, 1998). This argument suggests that if violence on behalf of Islam has been quasi absent in the continent prior to 1990 it is because Sufism allows for syncretism between Islamic beliefs and African traditions and focuses on promoting piety and spirituality as opposed to interfering in politics. According to this view, the rise of Salafism starting from the early 1990 have laid the ground for the rise of jihadist insurgency because contrary to Sufism, Salafism calls for de-Africanisation and politicisation of Islam.

The idea that Sufism is peaceful and apolitical is challenged by the nineteenth century Sufi jihads in West Africa, and neither Sufism nor Salafism fits the "local" versus "foreign" categorisation. West African Muslims, regardless of whether they are Sufi or Salafi constitute an integral part of the global Muslim community, and the dynamic of Islam in West Africa is influenced by the overall Muslim dynamics at the global level. Muslim activists in West Africa inspire and draw from Islamic ideologies that are developed and promoted at global level. Thus, it is important to underline that there is no African exceptionalism when it comes to the emergence of jihadist insurgency. The processes that have led to the wave of jihadist insurgency in West Africa are not any different from the process that led to the rise of the phenomenon elsewhere in the world. The wave of jihadist insurgency in West Africa comes as a result of the intersection of favourable conditions at the global, local, and individual level.

One of the fundamental challenges in dealing with jihadist insurgencies in West Africa and beyond - is the definition of concepts. How to define jihadism in a way that is inclusive enough to account for the important role played by certain interpretations of Islam, yet at the same time, parsimonious enough to prevent associating the entire religion of Islam with jihadist violence? The first step is to differentiate between theology and political ideology. Theology refers to mere interpretation of religious dogma and creed, whereas ideology refers to the doctrine as it relates to political preferences and behaviour. Jihadism is a political ideology whereas Sufism and Salafism are theological doctrines. Jihadism should not be conflated with Salafism. Indeed, empowering mainstream Salafists who 
enjoy wide religious legitimacy to combat jihadists may be a particularly rewarding strategy for containing extremism. Amalgamating these different doctrines has often pushed moderate salafists into the hands of the jihadists, such as what happened in Mauritania in 2003. Promoting the arguments and perspectives of mainstream Sufism and Salafism, by contrast, has subsequently proven to be a highly effective strategy for isolating jihadists in Mauritania.

Jihadism is a global ideology, but it emerges as politicised and violent insurgencies in areas of limited statehood where society is riven by local cleavages which cannot be addressed by existing institutions. Traditional authorities and customary law have played a significant role in maintaining order in places where the state has limited presence. Decentralisation reform should take into account the importance of informal institutions and be very careful not to undermine existing sources of authority and social control. Indeed, wise policies may be designed to build on these non-state institutions to complement formal state institutions. A long-perspective approach to addressing jihadism is required, and must be premised on the need to build effective state authority and legitimate institutions.

Not all jihadists are ideologues. Some, perhaps most, have found themselves within jihadist movements for situational and strategic reasons. Recognising the particular grievances and motives of different groups and attempting to address them is necessary for denying jihadist entrepreneurs local support and recruitment bases. Negotiation may be possible with certain jihadist elements, and should not be ruled out. Great caution must be taken by states and by external actors to avoid undermining those local actors who are most effective at combating jihadism, and to avoid feeding the flames of jihadism by appearing to support ideological claims of anti-Islamic "crusades."

\section{REFERENCES}

Abul Ma'ali, M.M. (2014), Al-Qa'idah wa Hulafa'uha fi Azawad, Aljazeera Center for Studies, Doha.

ACLED (2017), "Africa Data, Version 6, 1997-2015", Armed Conflict Location \& Event Data Project, University of Sussex, www.acleddata.com/data.

Al-Maqlaat (2016), "The rampant eruption - Mass Takfir by Abu Maysarah Al-Shaami”, May 16, https://www.justpaste.it/Mass_Takfir (accessed on 13 April 2017).

Benmelech, E. and E. Klor (2016), "What Explains the Flow of Foreign Fighters to ISIS?", National Bureau of Economic Research, Working Paper No. 22190, April, DOI: http://dx.doi.org/10.3386/ W22190.

Bøås, M. (2015), "Crime, Coping, and Resistance in the Mali-Sahel Periphery", African Security, Vol. 8/4, pp. 299-319, DOl: http://dx.doi.org/10.1080/19392206.2015.1100506.

Brigaglia, A. (2015), "The Volatility of Salafi Political Theology, the War on Terror and the Genesis of Boko Haram", Diritto e questioni pubbliche, Vol. 15/2, pp. 175-201.

Herbst, J. (2000), States and Power in Africa: Comparative Lessons in Authority and Control, Princeton University Press, Princeton, ISBN: 9780691164144.

Holder, G. (2009), L'islam, nouvel espace public en Afrique, Paris, Karthala, ISBN: 9782811102548.

Idrissa, A. (2009), "The Invention of Order: Republic Code and Islamic Law in Niger", Ph.D. thesis, University of Florida.

Imazighen Libya TV (2013), Sheikh lyad ag Ghaly, YouTube video, January 14, https://www.youtube. com/watch? $v=i X J X m Y F c z j \& t=735$ s (accessed on 11 April 2017).

International Crisis Group (2016), "Exploiting Disorder: Al-Qaeda and the Islamic State", Crisis Group Special Report, March 14, https://www.crisisgroup.org/global/exploiting-disorder-alqaeda-and-islamic-state (accessed on 12 April 2017), ISBN: 978-0520239340.

Kepel, G. (1984), Muslim Extremism in Egypt: The Prophet and Pharaoh, University of California Press, Berkeley.

Krasner, S. and T. Risse (2014), "External Actors, State-Building, and Service Provision in Areas of Limited Statehood: Introduction”, Governance: An International Journal of Policy, Administration, and Institutions, Vol. 27/4, pp. 545-567, DOI: http://dx.doi.org/10.1111/gove.12065.

Last, M. (2008), "The Pattern of Dissent: Boko Haram in Nigeria 2009”, Annual Review of Islam in Africa, Vol. 10, pp. 7-11, http://www.humanities.uct.ac.za/usr/cci/news/Murray_Last.pdf. 
Le Cam, M. (2017), "Burkina Faso: Le principal commanditaire de l'attentat de Ouagadougou identifié”, Le Monde Afrique, March 24, http://www.lemonde.fr.

Lecocq, B. and P. Schrijver (2007), "The War on Terror in a Haze of Dust: Potholes and Pitfalls on the Saharan Front”, Journal of Contemporary African Studies, Vol. 25/1, pp. 141-166, DOI: http://dx.doi.org/10.1080/02589000601157147.

“Liqa'a ma'a Abul fadl, lyad ag Ghali” (2017), Al-Masra No 45, April 3.

Matfess, H. (2016), "Here's why so many people join Boko Haram, despite its notorious violence", The Washington Post, April 26, https://www.washingtonpost.com.

Mercy Corps (2016), "Motivation and Empty Promises: Voice of Former Boko Haram Combatants and Nigerian Youth", April, https://www.mercycorps.org/sites/default/files/Motivations\%20 and\%20Empty\%20Promises_Mercy\%20Corps_Full\%20Report_0.pdf (accessed on 12 April 2017)

Mohammed, K. (2014), "The Message and Methods of Boko Haram"n in Perouse de Montclos M.A. (eds.) Boko Haram: Islamism, Politics, Security and the State in Nigeria, pp. 9-32, http://horizon. documentation.ird.fr/exl-doc/pleins textes/divers15-04/010064362.pdf.

OECD/SWAC (2013), Conflict over Resources and Terrorism: Two Facets of Insecurity, Paris, OECD Publishing, DOI: http://dx.doi.org/10.1787/9789264190283-en.

Oxfam (2017), "Red Gold and Fishing in the Lake Chad Basin", Oxfam Briefing Note, February, https://www.oxfam.org/sites/www.oxfam.org/files/file_attachments/bn-red-gold-fishing-lakechad-010217-en.pdf (accessed on 11 April 2017)

Risse, T. (2011), "Governance in Areas of Limited Statehood: Introduction and Overview", in Risse, T. (ed.) Governance Without a State? Policies and Politics in Areas of Limited Statehood, Columbia University Press, New York, pp. 1-35, http://www.jstor.org/stable/10.7312/riss15120.

Ryder, N. (2015), The Financial War on Terrorism: A review of counter-terrorism financing strategies since 2001, Routledge, New York, ISBN: 9781134446971.

Sambe, B. (2016), "Dr. Bakary Sambe: Prevention is vital as West African Countries Battle the Rise of Violent Extremism", http://timbuktu-institute.org/prevention-is-vital-as-west-african-countriesbattle-the-rise-of-violent-esxtremism/ (accessed on 12 April 2017).

Sambe, B. (2014), "Le Sénégal à l'épreuve de la crise sahélienne : Nouvelles dynamiques et reconfiguration du champ islamique", Sahel Research Group Working Paper No. 9, October http://timbuktu-institute.org/wp-content/uploads/2016/04/Working-paper-Sahel-ResearchGroup.pdf.

Sangare, B. (2016), "Le Centre du Mali : épicentre du djihadisme ?" Groupe de recherche et d'information sur la paix et la sécurité, Note d'analyse du GRIP, May 20, http://www.grip.org/fr/ node/2008 (accessed on 12 July 2017)

Sedgwick, M. (2007), “Jihad, Modernity, and Sectarianism”, Nova Religio: The Journal of Alternative and Emergent Religions, Vol. 11/2, pp. 6-27, http://www.jstor.org/stable/10.1525/nr.2007.11.2.6.

Seignobos, C. (2016), "Lac Tchad: Tout comprendre de la stratégie des terroristes de Boko Haram", Le Monde Afrique, April 29, http://www.lemonde.fr/.

Siegel, J. (2017), "ISIS in Africa: Implication from Syria and Iraq", Africa Center for Strategic Studies, March 17, http://africacenter.org/spotlight/islamic-state-isis-africa-implications-syria-iraq-bokoharam-aqim-shabaab/ (accessed on 11 April 2017)

Thurston, A. (2016), Salafism in Nigeria: Islam, Preaching, and Politics, Cambridge University Press, Cambridge, ISBN: 9781107157439

Walther, O. and D. Christopoulos (2015), "Islamic terrorism and the Malian rebellion", Terrorism and Political Violence, Vol. 27/3, pp. 497-519, DOI: http://dx.doi.org/10.1080/09546553.2013.809340.

Walther, O. and W. Miles (eds.) (2018), African Border Disorders. Addressing Transnational Extremist Organizations, Abingdon, Routledge, ISBN: 9781138054684 (forthcoming).

Westerlund, D. and E.E. Rosander (1998), African Islam \& and Islam in Africa: Encounter Between Sufis and Islamists, Athens, Ohio University Press, ISBN: 978-0-8214-1214-5. 



\section{ALSO IN THE WEST AFRICAN PAPERS SERIES:}

Allen, T. and P. Heinrigs (2016), "Emerging Opportunities in the West African Food Economy", West African Papers, No. 1, OECD Publishing, Paris. http://dx.doi.org/10.1787/5jlvfj4968jb-en

Lewis, K. and C. Buontempo (2016), "Climate Impacts in the Sahel and West Africa: The Role of Climate Science in Policy Making", West African Papers, No. 2, OECD Publishing, Paris. http://dx.doi.org/10.1787/5jlsmktwjcd0-en

Gnisci, D. (2016), “Women's Roles in the West African Food System: Implications and Prospects for Food Security and Resilience", West African Papers, No. 3, OECD Publishing, Paris. http://dx.doi.org/10.1787/5jlpl4mh1hxn-en

Staatz, J. and F. Hollinger (2016), "West African Food Systems and Changing Consumer Demands", West African Papers, No. 4, OECD Publishing, Paris. http://dx.doi.org/10.1787/b165522b-en

Prieto Curiel, R., P. Heinrigs and I. Heo (2017), "Cities and Spatial Interactions in West Africa: A Clustering Analysis of the Local Interactions of Urban Agglomerations", West African Papers, No. 5, OECD Publishing, Paris. http://dx.doi.org/10.1787/57b30601-en

Walther, O. (2017), "Cross-border Co-operation Networks in West Africa", West African Papers, No. 06, OECD Publishing, Paris. http://dx.doi.org/10.1787/73298292-en

For more information on the series, please contact: lia.beyeler@oecd.org 